P. Linhardt, S. Strobl, J. Böhm, M. V. Biezma, R. Haubner

\title{
Heat Treatment Effect on the Microstructure and the Corrosion Resistance of Manganese-Aluminum Bronzes
}

\section{Einfluss von Wärmebehandlungen auf das Gefüge und die Korrosionsbeständigkeit von Mangan-Aluminium-Bronzen}

Received: February 27, 2020

Accepted: September 26, 2020

Translation: E. Engert

\section{Introduction}

Copper-aluminum-based multinary alloys play a prominent role in sea water applications, especially for ship propellers. Manganese is a relatively inexpensive alloying element. Thus, bronzes containing Mn may represent a cost-effective alternative to bronzes containing Ni. When wear occurs and repair welding is required, what's of interest is the post-heat treatment corrosion behavior.

A manganese-aluminum bronze (MAB) of the type CuMn12Al7Fe4Ni2 was examined metallographically and electrochemically in
Eingegangen: 27. Februar 2020

Angenommen: 26. September 2020

\section{Einführung}

Kupfer-Aluminium-Mehrstofflegierungen haben eine große Bedeutung bei Meerwasseranwendungen, insbesondere bei Schiffsschrauben. Da Mangan ein vergleichsweise billiger Legierungsbestandteil ist, könnten Mn-haltige Bronzen eine kostengünstige Alternative zu den Ni-haltigen Bronzen darstellen. Wenn Verschleiß auftritt und Reparaturschweißungen durchgeführt werden müssen, ist das Korrosionsverhalten der Legierungen nach dieser Wärmebehandlung von Interesse.

Eine Mangan-Aluminium-Bronze (MAB) des Typs CuMn12Al7Fe4Ni2 wurde im gegossenen Anlieferungszustand sowie nach zwei Wärme-

\section{Authors:}

Paul Linhardt, Susanne Strobl, Julia Böhm, Roland Haubner Technische Universität Wien, Institut für Chemische Technologien und Analytik, Getreidemarkt 9/164-CT, A-1060 Wien, Österreich; e-mail: roland.haubner@tuwien.ac.at

Maria Victoria Biezma University of Cantabria, Dept. of Earth and Materials Science and Engineering, VCC/Dique de Gamazo 1, 39004 Santander, Spain 
the as-received as-cast condition and after two heat treatments at $850^{\circ} \mathrm{C}$ and $600^{\circ} \mathrm{C}$, respectively. Heat treatment and cooling rate determine the microstructure's fraction of the $\beta$ phase which is characterized by a low corrosion resistance. At an Al content of $7 \mathrm{wt}$. \%, the bronze is located in the three-phase region consisting of $\alpha, \beta$, and $\kappa$ phase. Thus, the $\beta$ phase cannot be completely removed. Slow cooling or tempering at low temperatures, however, improve the MAB's corrosion resistance, especially in sea water.

\section{Samples, Sample Preparation, and Examination Methods}

\begin{abstract}
A MAB of the type CuMn12Al7Fe4Ni2 (analysis mass. \%: $72 \% \mathrm{Cu}, 12 \% \mathrm{Mn}, 7 \% \mathrm{Al}$, 4 \% Fe, 2 \% Ni, 2 \% Zn, 0.08 Si, 0.02 Pb, $0.01 \mathrm{Sn})$ was subjected to examinations in the following three different conditions: as-received as-cast condition (1); $850^{\circ} \mathrm{C}$, $1 \mathrm{~h}$, quenched in water (2); and $600^{\circ} \mathrm{C}, 2 \mathrm{~h}$, slowly furnace cooled (3).
\end{abstract}

The samples were cut for metallographic examinations before and after the corrosion tests using a cut-off machine. The sliced pieces were hot mounted, plane ground, and subsequently gradually ground and diamond polished up to a grit of $1 \mu \mathrm{m}$. The samples were examined in their polished and etched condition using a light optical microscope (LOM) and a scanning electron microscope (SEM). $\mathrm{FeCl}_{3}$ and $\left(\mathrm{NH}_{4}\right)_{2} \mathrm{CuCl}_{4}$ solutions were used as etchants [1].

The electrochemical corrosion investigations were performed in simulated fresh water (SFW) and sea water (SSW). For SFW, $1 \mathrm{mmol} \mathrm{NaHCO}_{3}$ and $0.5 \mathrm{mmol} \mathrm{Na} \mathrm{SO}_{4}$ per liter water were dissolved. These values were determined in a previous work [2]. SSW according to DIN 50905-4, section 4.1, does not only contain $\mathrm{NaHCO}_{3}$ and $\mathrm{MgSO}_{4}$ but also $\mathrm{NaCl}, \mathrm{MgCl}^{*} 6 \mathrm{H}_{2} \mathrm{O}$ and $\mathrm{CaCl}_{2}{ }^{*} 2 \mathrm{H}_{2} \mathrm{O}$. The $\mathrm{pH}$ value was adjusted to values be- behandlungen bei 850 und $600^{\circ} \mathrm{C}$ metallographisch und elektrochemisch untersucht. Wärmebehandlung und Abkühlgeschwindigkeit bestimmen den Anteil an $\beta$-Phase im Gefüge, welche eine geringe Korrosionsbeständigkeit zeigt. Da bei einem Al-Gehalt von 7 Gew.\% sich die Bronze im Dreiphasengebiet aus $\alpha, \beta$ und $\kappa-$ Phase befindet, kann die $\beta$-Phase nicht vollständig entfernt werden. Langsame Abkühlung oder Temperung bei niedrigen Temperaturen verbessern jedoch die Korrosionsbeständigkeit der MAB, vor allem in Meerwasser.

\section{Proben, Probenpräparation und Untersuchungsmethoden}

MAB des Typs CuMn12Al7Fe4Ni2 (Analyse Gew. \%: $72 \% \mathrm{Cu}, 12 \% \mathrm{Mn}, 7 \% \mathrm{Al}, 4 \% \mathrm{Fe}, 2 \%$ $\mathrm{Ni}, 2 \% \mathrm{Zn}, 0,08 \mathrm{Si}, 0,02 \mathrm{~Pb}, 0,01 \mathrm{Sn}$ ) wurde in drei verschiedenen Zuständen für die Untersuchungen herangezogen: gegossener Anlieferungszustand (1), $850^{\circ} \mathrm{C}, 1 \mathrm{~h}$, in Wasser abgeschreckt (2) und $600^{\circ} \mathrm{C}, 2 \mathrm{~h}$, langsam im Ofen abgekühlt (3).

Vor und nach den Korrosionsversuchen wurden die Proben für die metallographischen Untersuchungen mit einer Trennmaschine getrennt. Nach dem Warmeinbetten und Planschleifen der zerkleinerten Teile wurden sie stufenweise bis $1 \mu \mathrm{m}$ Diamant geschliffen bzw. poliert. Die Proben wurden im polierten und geätzten Zustand mittels Lichtmikroskop (LOM) und Rasterelektronenmikroskop (REM) untersucht. Als Ätzmittel dienten $\mathrm{FeCl}_{3}$ - sowie $\left(\mathrm{NH}_{4}\right)_{2} \mathrm{CuCl}_{4}$ - Lösung [1].

Die elektrochemischen Korrosionsuntersuchungen wurden in simuliertem Süß- (SSW) und Meerwasser (SMW) durchgeführt. Für SSW wurden $1 \mathrm{mmol} \mathrm{NaHCO}_{3}$ und $0,5 \mathrm{mmol}$ $\mathrm{Na}_{2} \mathrm{SO}_{4}$ pro Liter Wasser gelöst, diese Werte resultierten aus einer früheren Arbeit [2]. SMW gemäß DIN 50905-4, Abschnitt 4.1 enthält neben $\mathrm{NaHCO}_{3}$ und $\mathrm{MgSO}_{4}$ noch $\mathrm{NaCl}$, $\mathrm{MgCl}{ }^{*} 6 \mathrm{H}_{2} \mathrm{O}$ und $\mathrm{CaCl}_{2}{ }^{*} 2 \mathrm{H}_{2} \mathrm{O}$. Der $\mathrm{pH}$-Wert wurde mittels $\mathrm{NaOH}$ auf Werte zwischen 7 und 
tween 7 and 8 by adding $\mathrm{NaOH}$. A saturated calomel electrode (SCE, $0 \mathrm{mV}_{\mathrm{SCE}}=$ $+242 \mathrm{mV}_{\mathrm{H}}$ ) was used as reference electrode.

The measurements were performed using a multi-channel potentiostat (Octopoti, [3]).

\section{Examination Results and Discus- sion}

\subsection{Microstructure of the manganese- aluminum bronzes}

The microstructure of the MAB alloys is similar to the microstructure of the better-known nickel-aluminum bronzes (NAB) [4]. It is a function of the composition and the manufacturing process (Fig. 1). The microstructure is dominated by $\alpha$ phase, which is copperenriched, and of the $\beta$ phase. If the melt cools down rapidly, the martensitic $\beta$ ' phase is preserved. At elevated proportions of $\mathrm{Mn}, \mathrm{Fe}$, and $\mathrm{Ni}$, different $\kappa$ phases form which contain higher amounts of $\mathrm{Mn}$ and $\mathrm{Fe}[5,6]$.
8 eingestellt. Als Referenzelektrode wurde eine gesättigte Kalomelelektrode (SCE, $0 \mathrm{mV}_{\mathrm{SCE}}=$ +242 $\mathrm{mV}_{\mathrm{H}}$ ) verwendet.

Die Messungen wurden mit einem MultikanalPotentiostaten (Octopoti, [3]) durchgeführt.

\section{Untersuchungsergebnisse und Diskussion}

\subsection{Mikrostruktur der Mangan-Aluminium- Bronzen}

Die Mikrostruktur der MAB Legierungen ist ähnlich jener der bekannteren Nickel-AluminiumBronzen (NAB) [4], sie hängt sowohl von der Zusammensetzung als auch vom Herstellungsprozess ab (Bild 1). Das Gefüge wird von einer kupferreicheren $\alpha$-Phase und der $\beta$-Phase dominiert. Kühlt die Schmelze rasch ab, so bleibt die martensitische $\beta$ '-Phase erhalten. Bei erhöhten Anteilen an Mn, Fe und Ni bilden sich unterschiedliche $\kappa$-Phasen, in denen höhere Gehalte an Mn und Fe vorhanden sind $[5,6]$.

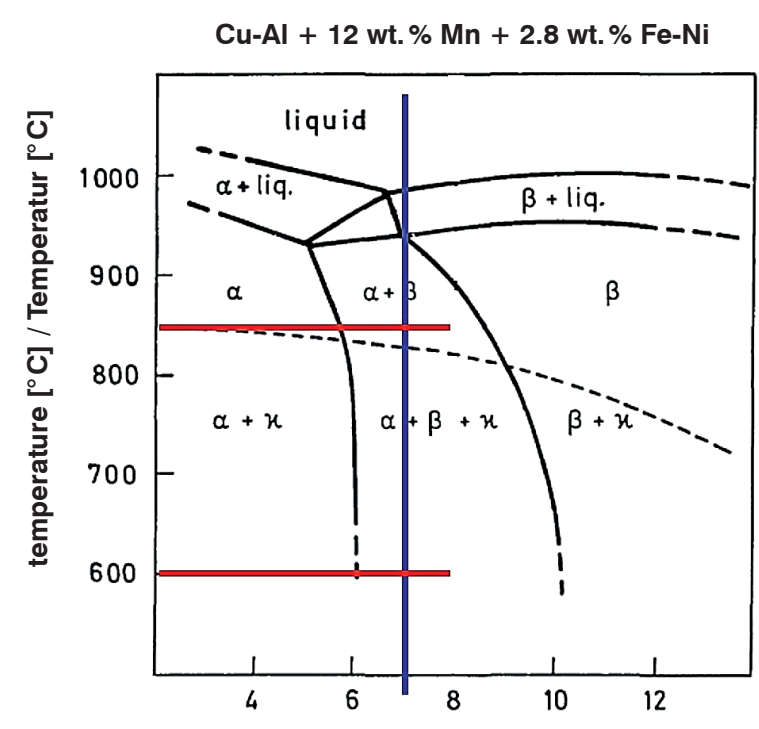

aluminum [wt. \%] / Aluminium [Gew. \%]
Fig. 1: Cu-Al-Mn phase diagram showing the temperatures of the respective heat treatments (diagram according to $P$. Brezina [6]).

Bild 1: Cu-Al-Mn Phasendiagramm mit den eingezeichneten Temperaturen der Wärmebehandlungen (Diagramm nach P. Brezina [6]). 


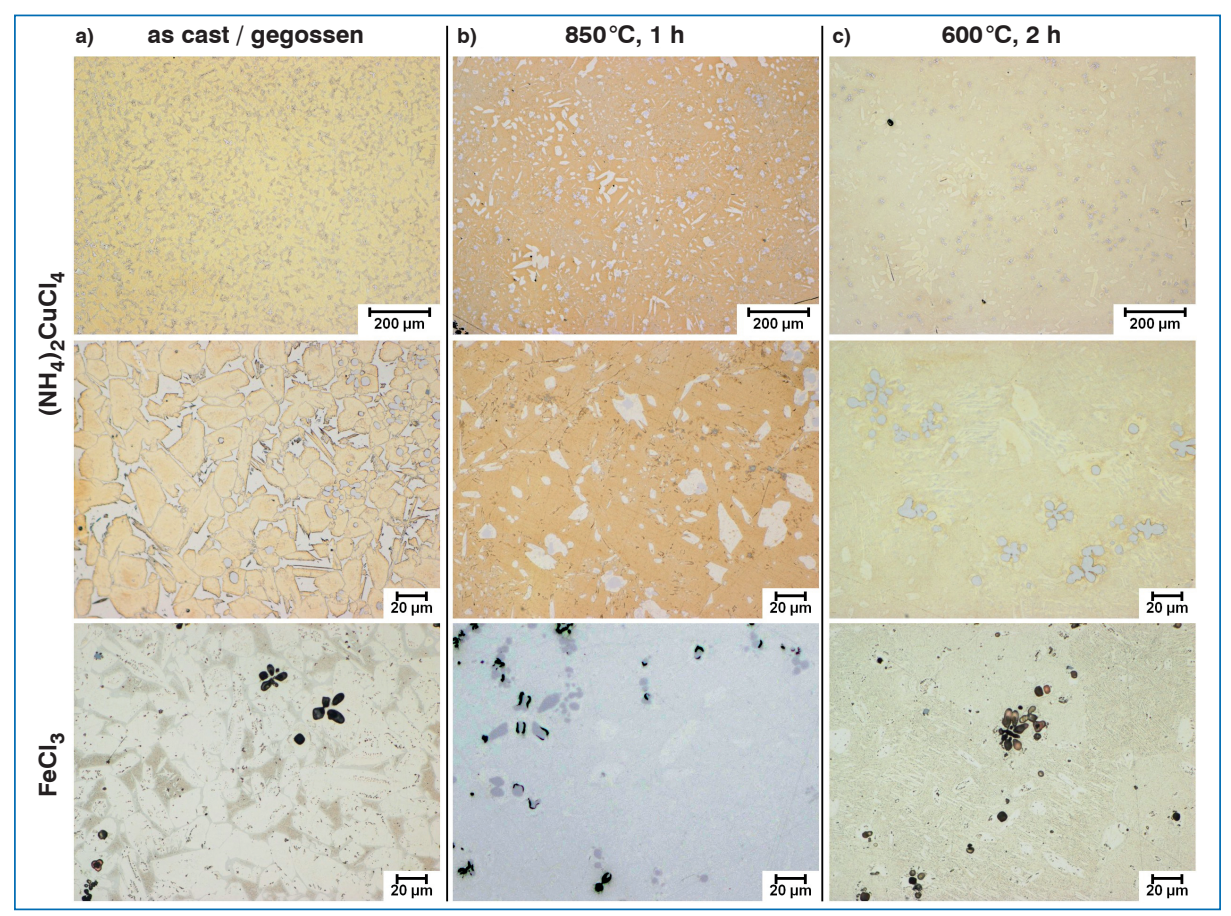

Figs. 2a to c: Microstructure of the examined samples before and after the heat treatments in the LOM. Etched using $\left(\mathrm{NH}_{4}\right)_{2} \mathrm{CuCl}_{4}$ and $\mathrm{FeCl}_{3}$, respectively.

Bilder 2a bis c: Gefüge der untersuchten Proben vor und nach den Wärmebehandlungen im LOM. $\left(\mathrm{NH}_{4}\right)_{2} \mathrm{CuCl}_{4}$ und $\mathrm{FeCl}_{3}$ Ätzungen.

The two etchants used provide slightly varying phase contrast results. Using $\mathrm{FeCl}_{3}$, the $\alpha$ phase appears white, the $\beta$ phase appears light gray, and the $\kappa$ phase appears black. Etching using copper ammonium chloride yields a yellowish $\alpha$ phase, a light gray $\beta$ phase, and a dark gray $\kappa$ phase (Fig. 2).

- As cast: The microstructure consists of $\alpha$ phase in which the $\beta$ phase is networklike arranged. The $\kappa$ phase is coarsely dendritic (Fig. 2a).

- Annealing at $850^{\circ} \mathrm{C}, 1 \mathrm{~h}$ : Etching reveals that not only coarse $\alpha$ and $\beta$ phase but also fine $\alpha / \beta$ phase mixtures are present in the structure. This can presumably be attributed to the water quenching process.
Die verwendeten Ätzmittel zeigen etwas unterschiedliche Kontrastierungen des Gefüges. Mit $\mathrm{FeCl}_{3}$ erscheinen die $\alpha$-Phase weiß, die $\beta$-Phase hellgrau und die $\kappa$-Phase schwarz. Die Ätzung mit Kupferammoniumchlorid färbt die $\alpha$-Phase gelblich, die $\beta$-Phase hellgrau und die $\kappa$-Phase dunkelgrau (Bild 2).

- Gusszustand: Das Gefüge besteht aus $\alpha$-Phase, in der die $\beta$-Phase netzartig angeordnet ist, und die $\kappa$-Phase liegt grob dendritisch vor (Bild 2a).

- $850^{\circ} \mathrm{C}, 1 \mathrm{~h}$ Glühung: Anhand der Ätzungen ist ersichtlich, dass neben grober $\alpha$ - und $\beta$-Phase auch feine $\alpha-\beta$-Phasengemische vorliegen. Dies ist vermutlich auf die Abschreckung in Wasser zurückzuführen. 
The annealing process brought about a coarsening of the $\kappa$ phase (Fig. 2b).

- Annealing at $600^{\circ} \mathrm{C}, 2 \mathrm{~h}$ : Owing to the annealing process and slow cooling, coarse $\alpha$ phase and a fine $\alpha / \beta$ mix can be observed. The $\kappa$ phase now has a rather globular appearance (Fig. 2c).

\subsection{Potentiostatic Corrosion Tests in Simulated Fresh Water}

The results of the potentiostatic measurements at different potentials are summarized in Fig. 3. The chart presents the current densities after a test duration of 72 hours.

Two different current-time curves were observed (Fig. 4). With increasing measurement time, rather low potentials are accompanied by a significant drop of the the initially higher current. The shape of the curve indicates a general corrosion attack attack involving surface layer formation. Smaller current peaks in this curve are interpreted as effects of local corrosion processes. At higher potentials, however, the current increases up to a certain level and subsequently increases only slightly.

The lowest current density, i. e. the highest corrosion resistance in SFW, can be observed in the cast sample (see Fig. 3) for each potential, respectively. This means that the applied annealing processes re-
Durch die Glühung hat sich die $\kappa$-Phase vergröbert (Bild 2b).

- $600^{\circ} \mathrm{C}, 2 \mathrm{~h}$ Glühung: Aufgrund der Glühung und langsamen Abkühlung erkennt man grobe $\alpha$-Phase und ein feines $\alpha-\beta$ Gemisch. Die $\kappa$-Phase erscheint jetzt eher globular (Bild 2c).

\subsection{Potentiostatische Korrosionsversuche in simuliertem Süßwasser}

Die Ergebnisse der potentiostatischen Messungen bei unterschiedlichen Potentialen sind in Bild 3 zusammengefasst, dargestellt sind die Stromdichten nach 72 Stunden Versuchsdauer.

Es wurden zwei unterschiedliche Strom/ZeitVerläufe beobachtet (Bild 4). Bei eher niedrigen Potentialen fällt der anfänglich höhere Strom mit zunehmender Messdauer deutlich ab. Die Form der Kurve deutet auf einen flächigen Angriff mit Deckschichtbildung hin. Kleinere Stromspitzen in diesem Verlauf werden als Auswirkungen von lokalen Korrosionsvorgängen interpretiert. Bei höheren Potentialen steigt der Strom dagegen bis zu einem bestimmten Niveau an und nimmt danach nur noch geringfügig zu.

Die geringste Stromdichte, d. h. den höchsten Korrosionswiderstand in SSW, zeigt in Bild 3 für jedes Potential die gegossene Probe. Das bedeutet, dass durch die angewendeten Glühungen eine Verschlechterung der

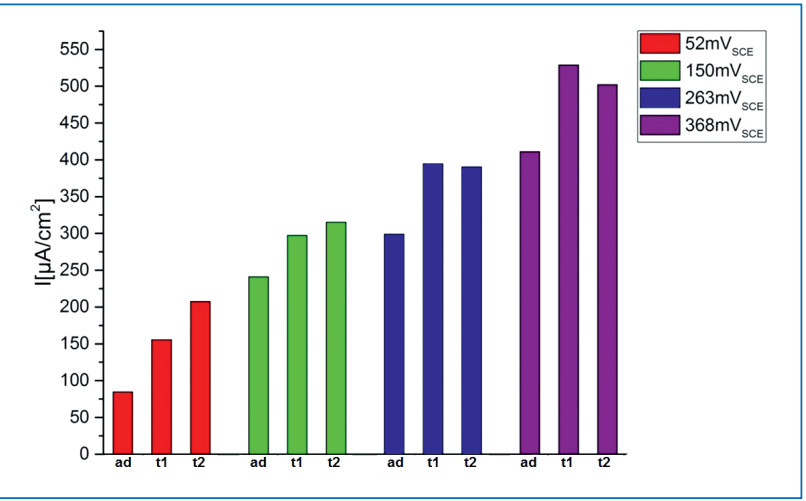

Fig. 3: Summary of the results of the potentiostatic measurement at different potentials in SFW: Anodic current densities after 72 hours. $\mathrm{ad}=\mathrm{cast}, \mathrm{t} 1=850^{\circ} \mathrm{C} 1 \mathrm{~h}$, $t 2=600^{\circ} \mathrm{C} 2 \mathrm{~h}$.

Bild 3: Zusammenfassung der potentiostatischen Messung bei verschiedenen Potentialen in SSW: Anodische Stromdichten nach 72 Stunden. ad = gegossen, $t 1=850^{\circ} \mathrm{C} 1 \mathrm{~h}, \mathrm{t} 2=600^{\circ} \mathrm{C} 2 \mathrm{~h}$. 


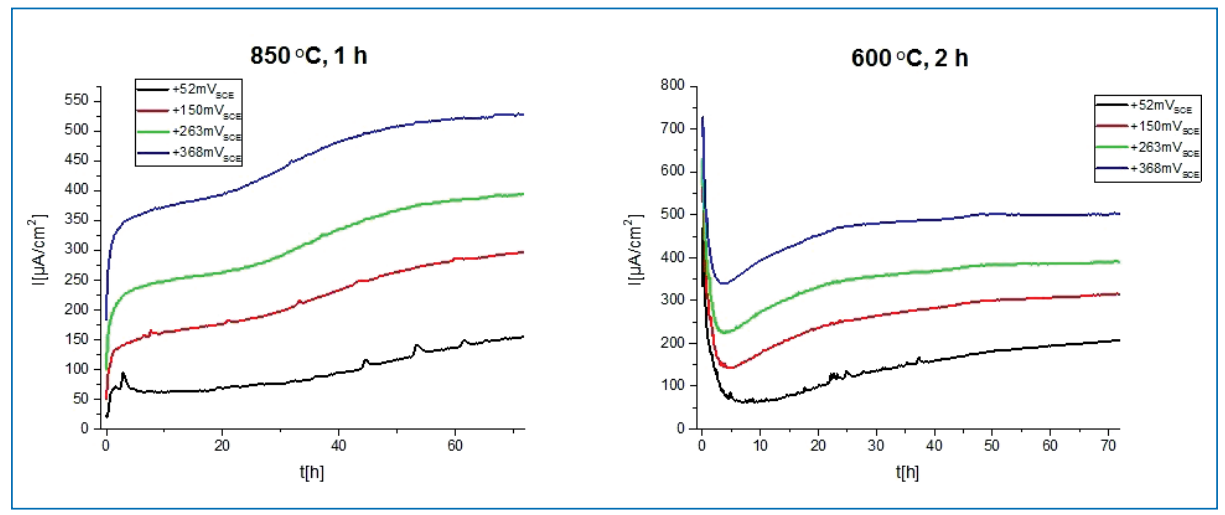

Fig. 4: Potential curves for the heat-treated samples in SFW at different potentials.

Bild 4: Potentialverläufe der wärmebehandelten Proben in SSW bei unterschiedlichen Potentialen.

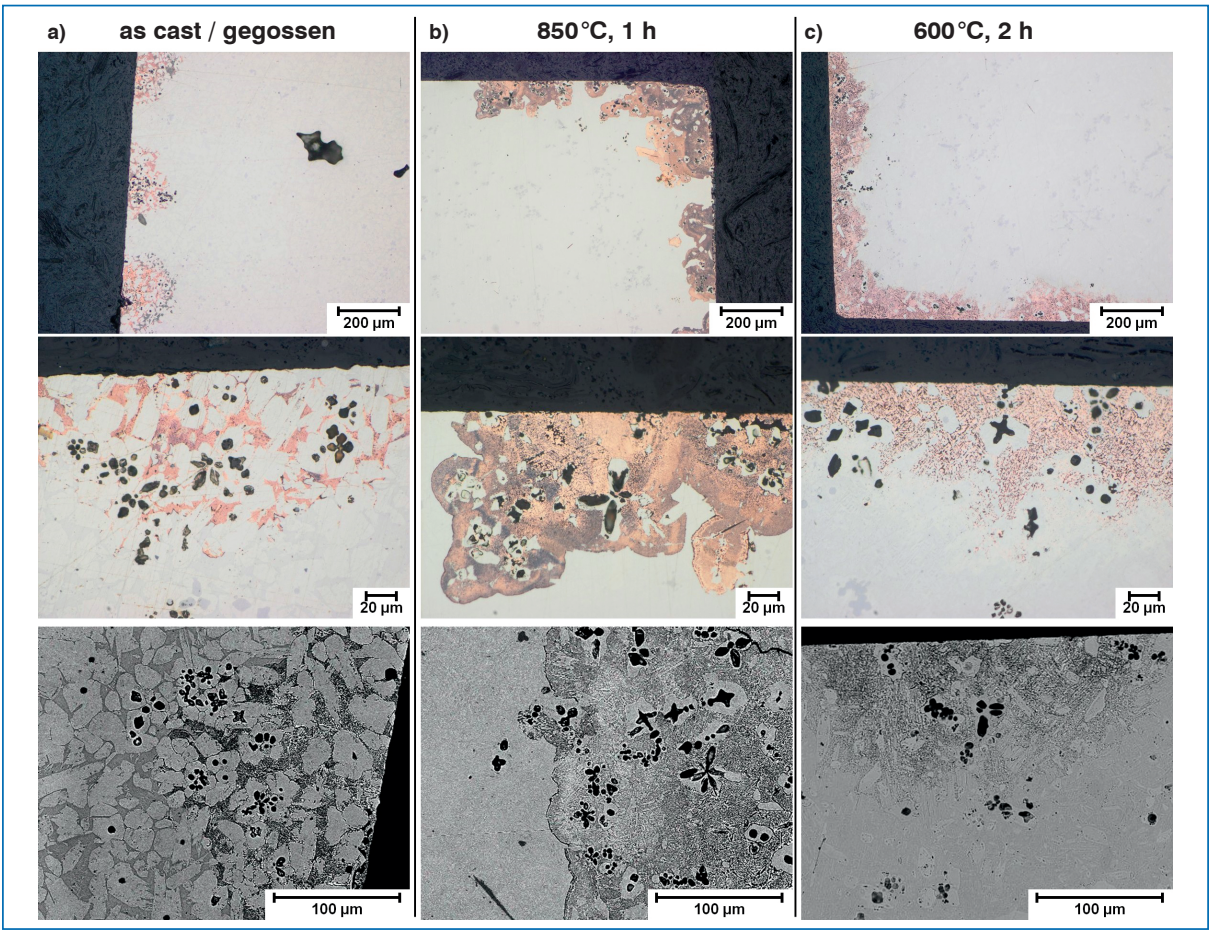

Figs. 5 a to c: Cross sections (unetched) of the samples corroded in SFW at a potential of $+368 \mathrm{mV} V_{S C E}$, LOM and SEM (bottom row).

Bilder 5a bis c: Querschliffe (ungeätzt) der in SSW bei einem Potential von $+368 m V_{S C E}$ korrodierten Proben, LOM und REM (untere Reihe). 
duce the corrosion resistance. The cross sections of the corroded samples which were tested at $+368 \mathrm{mV}_{\mathrm{SCE}}$ are summarized in Fig. 5. After the 72-hr potentiostatic tests, a general corrosion attack can be observed on all the samples.

- As cast: When viewed at higher magnifications, the cross sections reveal that the $\beta$ phase preferentially corrodes and that only metallic copper remains. It can further be recognized that the $\kappa$ phase is also attacked (Fig. 5a).

- Annealing at $850^{\circ} \mathrm{C}, 1 \mathrm{~h}$ : In the course of the test, the $\kappa$ phase is dissolved and dimples were formed. The $\beta$ phase and finer $\alpha / \beta$ phase mixtures were also attacked and transformed to copper which partially oxidized to $\mathrm{Cu}_{2} \mathrm{O}$ (Fig. 5b). Coarse $\alpha$ grains exhibit no corrosive attack.

- Annealing at $600^{\circ} \mathrm{C}, 2$ h: Here again, a general corrosion attack of the $\alpha / \beta$ phase mixtures and a local formation of dimples induced by $\kappa$ phase dissolution can be observed (Fig. 5c). Coarse $\alpha$ phase does not corrode.

The SEM examinations and images (Fig. 5a-c, bottom) confirm the metallographic findings.

\subsection{Potentiostatic Corrosion Tests in Simulated Sea Water}

The results of the potentiostatic measurement in SSW are summarized in Fig. 6. Here again, two different current-time curves were observed (Fig. 7). At rather low potentials and with increasing measurement time, the current decreases up to a relatively low level, indicating a general corrosion attack involving surface layer formation. At higher potentials, the current increases sharply and subsequently remains at a very high level.

This representation of the results (Fig. 4) shows that the sample annealed at $800^{\circ} \mathrm{C}$ has a higher current density and thus ex-
Korrosionsbeständigkeit eintritt. Die Querschnitte der korrodierten Proben, welche bei $+368 \mathrm{mV}_{\text {SCE }}$ getestet wurden, sind in Bild 5 zusammengefasst. Nach den potentiostatischen Versuchen über 72 Stunden ist auf allen Proben flächiger Angriff zu erkennen.

- Gusszustand: Querschliffe bei höherer Vergrößerung zeigen, dass bevorzugt die $\beta$-Phase korrodiert und nur noch metallisches Kupfer zurückbleibt. Des Weiteren ist erkennbar, dass auch die $\kappa$ - Phase angegriffen wird (Bild 5a).

- $850^{\circ} \mathrm{C}, 1 \mathrm{~h}$ Glühung: Die к-Phase wird während der Versuche aufgelöst und es entstanden Grübchen. Die $\beta$-Phase und feine $\alpha-\beta$-Phasengemische wurde ebenfalls angegriffen und in Kupfer umgewandelt, welches teilweise $\mathrm{zu} \mathrm{Cu}_{2} \mathrm{O}$ oxidiert ist (Bild 5b). Grobe $\alpha$-Körner zeigen keinen korrosiven Angriff.

- $600^{\circ} \mathrm{C}, 2$ h Glühung: Auch hier ist ein flächigen Angriff der $\alpha-\beta$-Phasengemische und lokale Grübchenbildung durch к-Phasenauflösung zu beobachten (Bild 5c). Grobe $\alpha$-Phase korrodiert nicht.

Die REM Untersuchungen und Bilder (Bild $5 \mathrm{a}-\mathrm{C}$, unten) bestätigen die metallographischen Befunde.

\subsection{Potentiostatische Korrosionsversuche in simuliertem Meerwasser}

Die Ergebnisse der potentiostatischen Messung in SMW sind in Bild 6 zusammengefasst. Auch hier wurden zwei unterschiedliche Strom/Zeit-Verläufe beobachtet (Bild 7). Bei eher niedrigen Potentialen fällt der Strom mit zunehmender Messdauer bis zu relativ niedrigem Niveau ab, was auf flächigen Angriff mit Deckschichtbildung hindeutet. Bei höheren Potentialen steigt der Strom stark an und bleibt danach auf sehr hohem Niveau.

Aus dieser Darstellung der Ergebnisse (Bild 4) geht hervor, dass die bei $800^{\circ} \mathrm{C}$ geglühte Probe eine höhere Stromdichte und somit 


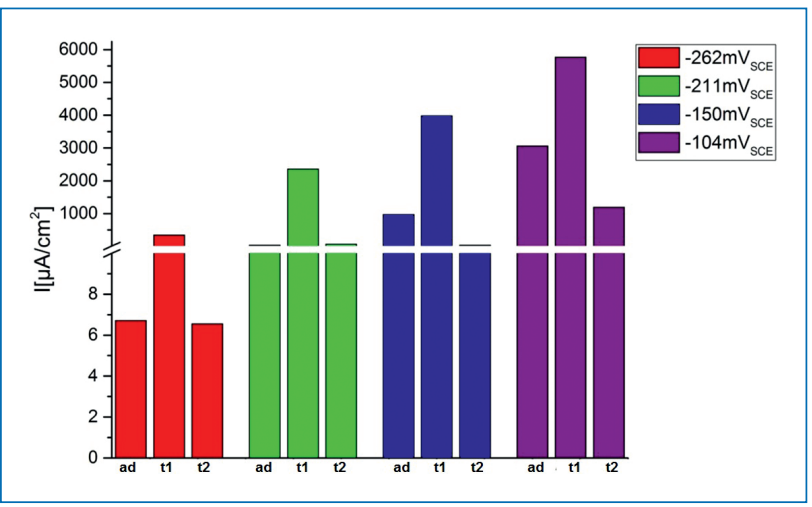

Fig. 6: Summary of the results of the potentiostatic measurement at different potentials in SSW: Anodic current densities after 72 hours. $a d=$ cast, $t 1=$ $850^{\circ} \mathrm{C} 1 \mathrm{~h}, \mathrm{t} 2=600^{\circ} \mathrm{C} 2 \mathrm{~h}$.

Bild 6: Zusammenfassung der potentiostatischen Messung bei verschiedenen Potentialen in SMW: Anodische Stromdichten nach 72 Stunden. ad $=$ gegossen, $t 1=$ $850^{\circ} \mathrm{C} 1 \mathrm{~h}, \mathrm{t2}=600^{\circ} \mathrm{C} 2 \mathrm{~h}$.

hibits a lower corrosion resistance than the cast sample and the sample annealed at $600^{\circ} \mathrm{C}$.

Views of the cross sections of the corroded samples tested at -104 $\mathrm{mV}_{\mathrm{SCE}}$ are summarized in Fig. 8.

- As cast: In this sample, the $\beta$ phase was subject to a general corrosion attack and the phase transformed to copper. The $\kappa$ phase and, to a lesser extent, the $\alpha$ phase were subject to corrosion (Fig. 8a).

- Annealing at $850^{\circ} \mathrm{C}, 1 \mathrm{~h}$ : The cross-sectional views of the sample are summarized geringeren Korrosionswiderstand aufweist, als die gegossene und auch die bei $600^{\circ} \mathrm{C}$ geglühte Probe.

Ansichten der Querschnitte der korrodierten Proben, welche bei -104 mV $\mathrm{mSE}_{\text {SCE }}$ getestet wurden, sind in Bild 8 zusammengefasst.

- Gusszustand: Bei dieser Probe kam es zu flächigem Angriff der $\beta$-Phase, welche sich in Kupfer umgewandelt hat. Teilweise wurden auch die $\kappa$-Phase und in geringerem Ausmaß auch die $\alpha$-Phase korrodiert (Bild 8a).

- $850^{\circ} \mathrm{C}, 1 \mathrm{~h}$ Glühung: Die Querschnittsansichten der Probe sind in Bild 8b zu-

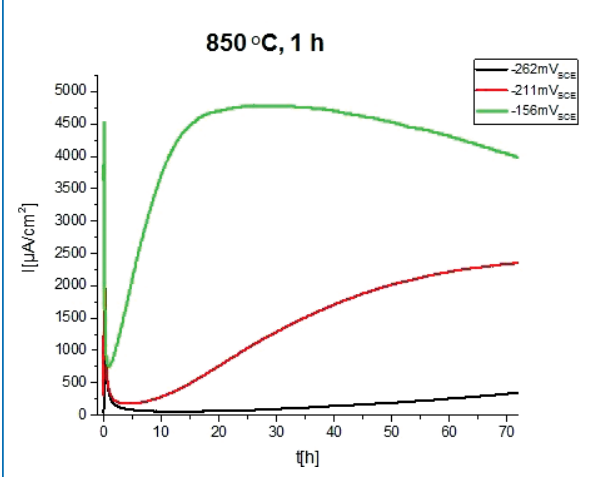

$600^{\circ} \mathrm{C}, 2 \mathrm{~h}$

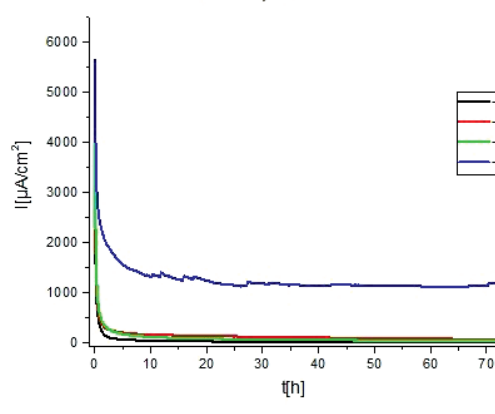

Fig. 7: Potential curves of the heat-treated samples in SSW at different potentials.

Bild 7: Potentialverläufe der wärmebehandelten Proben in SMW bei unterschiedlichen Potentialen. 


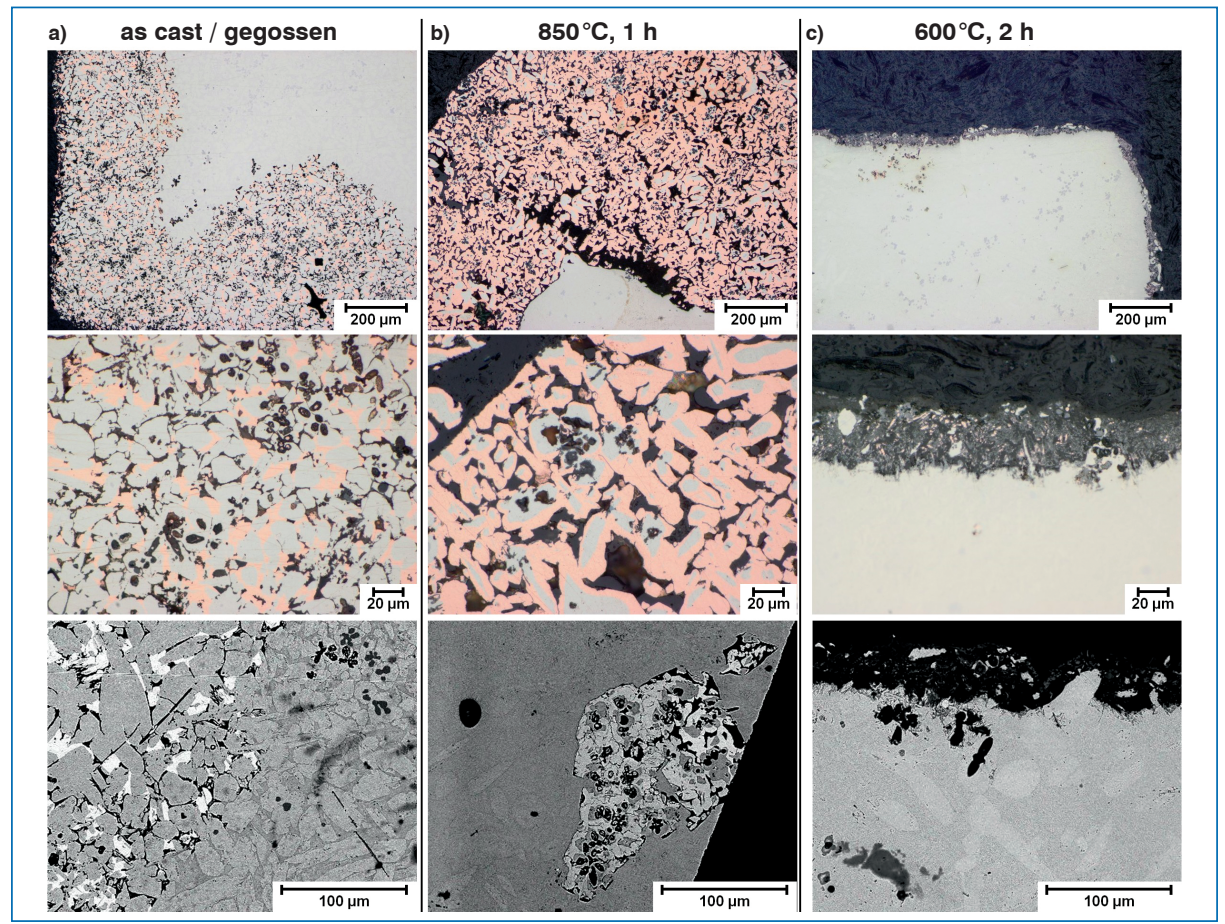

Figs. 8 a to c: Cross sections (unetched) of the samples corroded in SSW at a potential of $-104 \mathrm{mV}_{\text {SCE }}$, LOM and SEM (bottom row).

Bilder 8 a bis c: Querschliffe (ungeätzt) der in SMW bei einem Potential von -104 $m V_{S C E}$ korrodierten Proben, LOM und REM (untere Reihe).

in Fig. 8b. It can be observed that, here again, a selective attack of the $\beta$ phase took place involving the precipitation of copper (dealloying). The $\kappa$ phase was subject to corrosion. Locations in which fine lamellar $\alpha / \beta$ phase mixtures were present seem too be most strongly attacked.

- Annealing at $600^{\circ} \mathrm{C}, 2 \mathrm{~h}$ : Here, a general corrosion attack accompanied by a slight formation of depressions can be observed. Large $\alpha$ grains are not attacked. $\kappa$ phase and especially the fine $\alpha / \beta$ mixture are subject to corrosion (Fig. 8c).

Here again, the metallographic findings are confirmed by the SEM analyses and images (5a-c, bottom). sammengefasst. Man erkennt, dass es auch hier zu einem selektiven Angriff der $\beta$-Phase unter Kupferausscheidung kam (Dealloying) und die $\kappa$-Phase wurde korrodiert. Am stärksten erscheinen jene Lokalitäten angegriffen, wo feinlamellare $\alpha-\beta$-Phasengemische vorgelegen haben.

- $600^{\circ} \mathrm{C}, 2$ h Glühung: Hier erkennt man flächigen Angriff mit leichter Muldenbildung. Große $\alpha$-Körner werden nicht angegriffen, $\kappa$-Phase und vor allem das feine $\alpha-\beta-$ Gemisch werden korrodiert (Bild 8c).

Auch hier werden die metallographischen Befunde durch die REM Untersuchungen und Bilder (5a-c, unten) bestätigt. 


\section{Summary}

The analyses have shown that the corrosion behavior of manganese-aluminum bronzes (MAB) can be improved by keeping the fraction of $\beta$ phase low. As opposed to the cast structure, the sample annealed at $850^{\circ} \mathrm{C}$ and water quenched does not only contain coarse $\alpha$ and $\beta$ phase but also a fine $\alpha / \beta$ phase mixture. The $\kappa$ phase is coarsened. After annealing at $600^{\circ} \mathrm{C}$, not only isolated coarse $\alpha$ phase but also a fine $\alpha / \beta$ phase mixture is present. The $\kappa$ phase has a globular appearance. Since, at an $\mathrm{Al}$ content of $7 \mathrm{wt}$. \%, the alloy is located in a three-phase region consisting of $\alpha, \beta$, and $\kappa$ phase, the $\beta$ phase is preserved even at slow cooling.

In both corrosive media, SFW and SSW, predominantly selective corrosion takes place after which, similar to the dezincification of brass, metallic copper remains (so-called dealloying). The heat treatments show different effects on the corrosion behavior in fresh water or sea water. In fresh water, both heat treatments result in a deterioration of the corrosion resistance. Here, the $\alpha-\beta$ phase mixture, the $\beta$ phase, and the $\kappa$ phase were attacked.

Measurements in sea water revealed a deterioration of the durability after annealing at $850^{\circ} \mathrm{C}$, but an improvement after annealing at $600^{\circ} \mathrm{C}$. Since no coarse $\beta$ phase is observed after slow cooling, the MAB corrosion resistance, especially to sea water, can thus be improved.

\section{References / Literatur}

[1] Vander Voort, G.F.: Metallography. ASM International, $3^{\text {rd }}$ printing, 2004..

[2] Linhard, P.: Unusual corrosion of nickel-aluminium bronze in a hydroelectric power plant, Materials and Corrosion, 66, 2015, 1536-1541 DOl: $10.1002 /$ maco. 201508323

\section{Zusammenfassung}

Die Untersuchungen haben gezeigt, dass bei Mangan - Aluminium - Bronzen (MAB) das Korrosionsverhalten verbessert werden kann, indem man den Anteil an $\beta$-Phase gering hält. Im Vergleich zum Gussgefüge enthält die bei $850^{\circ} \mathrm{C}$ geglühte und in Wasser abgeschreckte Probe neben grober $\alpha$ - und $\beta$-Phase ein feines $\alpha-\beta$-Phasengemisch und die $\kappa$-Phase ist vergröbert. Nach Glühung bei $600^{\circ} \mathrm{C}$ tritt neben vereinzelt grober $\alpha$-Phase ein feines $\alpha-\beta$-Phasengemisch auf, die $\kappa$-Phase hat sich eingeformt. Da sich die Legierung bei einem Al-Gehalt von 7 Gew.\% in einem drei Phasengebiet, bestehend aus $\alpha, \beta$, -Phase befindet, bleibt auch bei langsamem abkühlen noch $\beta$-Phase bestehen.

In beiden Korrosionsmedien, SSW und SMW, kommt es vorwiegend zu selektiver Korrosion, bei der, ähnlich wie bei der Entzinkung von Messing, metallisches Kupfer zurückbleibt (sog. Dealloying). Die Wärmebehandlungen zeigen unterschiedliche Auswirkungen auf das Korrosionsverhalten in Süßwasser oder Meerwasser. Für Süßwasser führten beide Wärmebehandlungen zu einer Verschlechterung der Korrosionsbeständigkeit, wobei hier das $\alpha$ - $\beta$-Phasengemisch, die $\beta$-Phase und die $\kappa$-Phase angegriffen wurden.

Messungen in Meerwasser ergaben eine Verschlechterung der Beständigkeit nach der $850^{\circ} \mathrm{C}$ Glühung aber eine Verbesserung nach der $600^{\circ} \mathrm{C}$ Glühung. Da nach langsamer Abkühlung keine grobe $\beta$-Phase beobachtet wird, kann die Korrosionsbeständigkeit der MAB so vor allem gegenüber Meerwasser verbessert werden.

[3] Linhardt, P.; Kührer, S.; Ball, G.; Biezma, M.V.: Design of a multichannel potentiostat and its application to corrosion testing of nickel aluminium bronze, Materials and Corrosion 69, 2018, 358-364

DOI: $10.1002 / \operatorname{mac} 0.201709781$ 
[4] Böhm, J.; Linhardt, P.; Strobl, S.; Haubner, R.; Biezma, M.V.: Microstructure of a Heat Treated Nickel-Aluminum Bronze and Its Corrosion Behavior in Simulated Fresh and Sea Water, Materials Performance and Characterization 5, 2016, 689-700

DOI: 10.1520/MPC20160029

[5] Iqbal, J.; Hasan, F.; Ahmad, F.: Characterization of Phases in an As - cast Copper - Manganese - Aluminum Alloy. J. Mater. Svi. Technol., 22, 2006, 779-784

\section{Suanne Strobl}

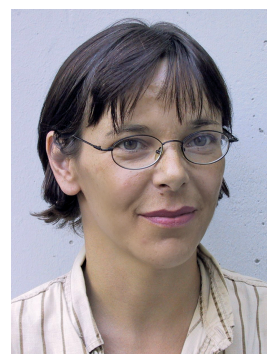

is working as a scientific officer at the Institute of Chemical Technologies and Analytics (TU-Wien) and is teaching supervisor of metallography. She studied chemistry and her doctoral thesis was about sintered steels.
[6] Brezina, P.: Heat treatment of complex aluminium bronzes. International Metals Reviews, 27, 1982, 77-120

DOI: $10.1179 / \mathrm{imr} .1982 .27 .1 .77$

\section{Bibliography}

DOI 10.1515/pm-2020-0004

Pract. Metallogr. 58 (2021) 2; page 72-82

(C) 2021 Walter de Gruyter $\mathrm{GmbH}$, Berlin/Boston, Germany

ISSN 0032-678X · e-ISSN 2195-8599

\section{Paul Linhardt}

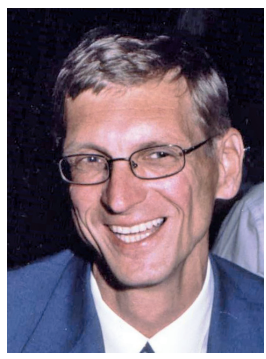

is Ao. Univ. Prof. at TUWien. He is specialized on corrosion of metallic materials with emphasis on electrochemical mechanisms and a particular field of interest is microbially influenced corrosion. A major part of his work is related to failure analysis and material testing. 